\title{
Code-switching as a Linguistic Resource in the Fijian ESL Classrooms: Bane or Boon?
}

\author{
Ravnil Narayan \\ Department of Communications and Media, School of Communication Languages and Literature, Fiji National \\ University, Fiji
}

\begin{abstract}
Code-switching is an unintentional linguistic phenomenon that defines a shift from one language to another by the speaker of a language. This study will address the role of code switching to students' L1 in their ESL classrooms and whether it expands interaction in these classrooms. Alternative language that is used in this paper for comparison and examples purpose is Fiji Hindi. The gap perceived in this area needs to be addressed towards the domains of sociolinguistics and applied linguistics in the ESL classrooms teaching milieu. Henceforth, the study draws on data collected from lower secondary $E S L$ classrooms in the selected high schools of Ba, Fiji. The study has incorporated data gathering procedures: questionnaire and semi-structured interviews. The findings ought to indicate that code-switching should be seen as an optimistic language learning strategical tool as part and parcel of the ESL classrooms discourse. The research is calling for sensitising teachers of ESL about the helpful uses of code-switching knowing the fact that Fiji is a second language speakers' of English country. Therefore, the novelty of this research would call for methods and syllabi of teaching ESL instructions to integrate code-switching in a judicious and occasional manner, wherever possible in the English language curriculum.
\end{abstract}

Index Terms-Code Switching, First language (L1), Second language (L2), English as a Second Language (ESL), Fiji Hindi, i-taukei

\section{INTRODUCTION}

Schools in Fiji often disallow learners from using a language other than the official medium of instruction, which is English. The paramount aim is to assist the learners to be proficient in the medium of instruction, thus excel in their studies. However, code-switching in between the lessons being taught, especially in ESL classrooms is highly evident and students who have low competency rate in English, they are more into using this linguistic feature to make sense with their fellow classmates and ESL teachers. In academic discussions, code-switching is particularly apparent during students' group work, whereby the most switching is done either in Fiji Hindi or i-taukei language.

However, scant research in the field of applied linguistics in the Fijian ESL classroom suggests that code-switching is carried out not only to fill the gap, when learners English is weak but also used to achieve a repertoire of discourse functions. The point that is being highlighted here is that learners are making use of the resources of bilingualism (Willians, 2011). This can be perceived as an advantage on the part of the learners', rather than being not in the position to meet the demands of the ESL classrooms. Crucially, these fecund patterns of communication are restricted by the English only policy in the classrooms, and thus are only practiced when the teacher is not present, or indirectly involved in the group discussions. Therefore, it could be contemplated that although the principal language of instruction in Fijian ESL classroom is English, this is not the language in which majority of genuine academic interaction takes place. So much so, it could be further asserted that the language policy should be reconsidered for the sake of the inclusion of code-switching as a language learning strategy, or else this could be highly detrimental for those, who are mediocre or below mediocre learners'.

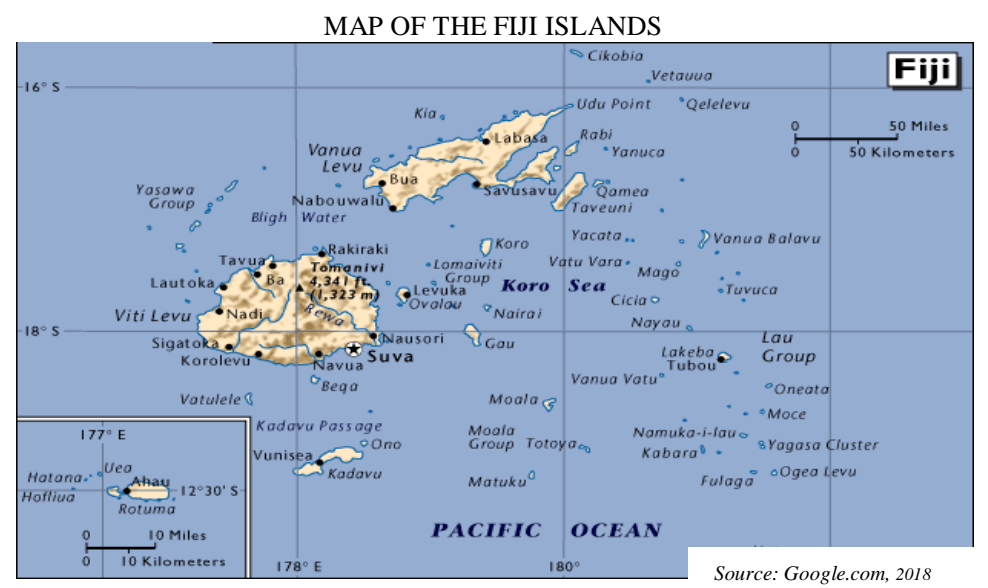




\section{THEORETICAL BACKGROUND}

A person is believed to be multilingual if he or she is competently able to use more than one language. In any given country, irrespective of the native language, multilingualism is usually borne out by results such as, colonialism, intercultural marriages, education, cultural interactions and so forth. According to Hymes (1972), communicative linguistic competence (CLC) looks into a speakers competency level in terms of when to speak, what to talk about with whom, when, where and in what manner.

In this way, a person who is able to converse appropriately into two languages is said to be bilingual. Usually, it has been highly noticed that bilinguals and multilinguals tend to switch languages within the same utterance of the conversation. In linguistics context, this phenomenon is referred to as code switching. Sociolinguists have tried to study this phenomenon and the reasons behind it. Interestingly, there are many factors that are associated with the phenomenon of code switching. Thus, this paper is divided into three parts, which will oversee the definition of the phenomenon of code switching, secondly, the reasons that contributes towards code switching and thirdly, the recommendations and the conclusion.

\section{OBJECTIVES OF THE STUDY}

The primary objective of this research is to examine the phenomenon pertaining to code switching in the Fijian ESL classrooms by the teachers of English language. A repertoire of reasons for code switching is identified by collecting and analysing the research questionnaires and through conducting semi-structured interviews. So much so, could code switching be should considered as a possible solution, as a linguistic resource to aid incompetent learners in ESL classrooms? These responses for this interrogation are gathered and looked into by the assistance of the English language teachers at junior level ESL classrooms.

\section{SIGNIFICANCE OF THE STUdy}

This study is going to fill the void and suffice the information towards the existing literature on code switching in the Fijian ESL classrooms. The information gained from this research will assist to provide a look into how and why code switching is done by teachers of ESL and what are the immediate repercussions of it. It is imperative as bilingual and multilingual teachers then to consider code switching as a language learning tool, which tends to aid the competency level of mediocre and below mediocre learner's. The information gathered from this study will assist to sensitise further research in the field of applied linguistics and sociolinguistics.

\section{RESEARCH QUESTIONS}

In the quest to do this study, the following are the questions on which the findings delved:

a. Why do teacher's code switch in ESL classrooms?

b. What role does code switching play in the meaningful interactions in ESL teaching?

c. How frequently is code switching used by teachers in ESL teaching?

d. When should L1 be used by the teacher?

\section{RESEARCH DESIGN}

The research survey for this study was gathered by opting for a mixed method approach. Research tools such as questionnaire and semi-structured interview was used for data collection. The questionnaire incorporated 5-point Likert scale, which comprised of open and closed ended questions. The items on the questionnaire consisted of five different sections that gathered the data on language use in the ESL classroom, teacher's perception, demography, reasons and frequency of code switching.

The research instruments were checked for validity and reliability as asserted by (Cohen et al, 2002) that "if a piece of research is invalid and unreliable, then it is worthless". The question of validity is imperative because it tends to ensure that the results of the study can be generalised to population studies. In terms of the interview, a total of eight respondents were taken on board for the interview sessions. Ten questions were created for the interviews, which was based on the four research questions that this study was aimed to investigate. As stated by Creswell (1998), taking consent from the respondents and respecting their anonymity are considered to be assurance for all due ethical considerations. As such, this study has purely applied the principles of ethical considerations in the most judicious manner.

\section{LITERATURE REVIEW}

Literature review has been surveyed extensively, which covered the reviews that emanated from Asia, Europe, America, the Africans and Middle East. As such, by definition, code-switching generally refers to a shift from one language to another by a speaker in a conversation. After going through various readings, it has been noted there are different, yet similar definition of code-switching. According to Fareed (2016), code switching is generally defined as a 
shift from L1 to L2 or vice-versa by the speaker during a speech. In his research, he also mentions that code switching is considered to be an interchangeable of two codes done by transfer, borrowing or mixing of words (Valdes-Fallis, 1978).

Gumperz (1982) defined code switching as the juxtaposition of two grammatical systems or sub-systems. On the other hand, Azlan \& Narasuman (2013) asserts that code switching is naturally a shift that occurs "between more than two languages simultaneously, within one conversation". It is a natural process, which does not require any consciousness but spontaneity.

According to Tamata (1996), a group of speakers who are bilingual is the prerequisite context for the incidence of code switching, that is, alternating between language varieties on the word, clause, phrase or at sentence level (cited in Lynch, 1996). It is further considered to be a natural phenomenon of acquiring a language other than one's own, only too natural for the speaker would use words and phrases from the native language to supplement the attempts of conversing in L2. Conversely, the speaker can, when speaking his or her native language use the L2 in order to convey the information. While putting the phenomena of code switching, the studies has also dwelled upon the functions of code switching in arrayed aspects. In other words, code switching is seen as an optimistic strategic feature to help those learners, who are having terrible English speaking background and those, who are rather incompetent users of the language itself.

Contrary to above, code switching is also seen as a pessimist approach to learning and teaching of English as a second language. As asserted by Bentahila (1983), Arabic-French bilinguals in Morocco have considered code switching as an impoverished form of expression, which is seen as a "bastard language" and is often considered to be attributed to lack of education, improper control of the grammars and is a "bad manners". So much so, code switching is seen as a speech for the semi-literates and those who switch "had no sense of identity" and "had a disturbed conscience". Speakers who switch from one language to another appeared to be rather sophisticated, to show off, and to appear to know L2 more. Such awfully pessimist views may echo attitudes towards English colonialism, whereby those who tend to code switch, do not have any pride in their own native language.

On an optimistic note, code switching can be considered as a language learning strategy to assist mediocre or below mediocre learners. The learners are able to express themselves easily and precisely, thus aiding in communication skills. For many bilingual and multilingual sentient people, code switching is seen as an informal and intimate register, which allows the speakers to converse in a more natural and relaxed manner. If a child converses in the classroom, when communicating to other classmates and even the teacher, it should be seen as a potential code for ESL learning and teaching. On a brighter side, code switching should not be seen as a breach of any English speaking policy in the schools, or as an inability of a student to express himself/herself in the language of instruction, English, with which comes the label of academic weakness. But as formal education system in Fiji normally requires teaching a standard language, the paramount achievement is to assist a learner succeed in the L2. As a consequence, any non-standard variety of a language is strongly discouraged because "the classroom has been identified as a domain, wherein a variety of language is used other than that found in ordinary conversation" (Valdes-Fallis, 1978). In a study conducted by Gumperz and Chávez (1972), if a teacher in Black American classroom imposes the use of standard language in the ESL classrooms, the communication amongst the students becomes monostylistic, which leads them to feel reluctant as much as frustrated to express themselves freely. The learners are restricted to one language variety and may feel that their variety is subservient and should be considered as a limited resource only.

Throughout the world, ESL/EFL classrooms are having optimistic and pessimistic deficiencies towards code switching (Abdolaziz \& Shahla, 2015). As suggested by Krashen (1982), the exposure to comprehend the required input is necessary for a successful second language acquisition. If the learners are not in a position to fathom what they are supposed to, they will not be comfortable in proceeding with a task. As such, ESL/EFL classroom educator's sometimes resort to learners L1 to elucidate and manage task with the hope that it will facilitate subtle learning ambience (Ellis, 2015). Code switching occur unconsciously by the teachers as a learning strategy in the amplification of instructions, managing classroom, making learners fathom difficult vocabularies and more imperatively reducing student nervousness (Jingxia, 2010). Code switching tends to serve as a mean towards providence for low proficient learners with the openings to communicate and enhancing of the lecture (Ahmad \& Jusoff, 2009).

As asserted by Moghadam, Samad \& Shahraki (2013), code switching does not only contribute towards an increase in students' comprehension and application of the material but it also provides a favorable learning milieu with the assistance of good teacher-student relationships. The below mediocre ESL learners think that they are really content that the teacher is elucidating things in their L1, which gives them a rather a solid platform to fathom what is being taught in the classroom (Nordin, Ali, Zubir \& Sadjirin, 2013). According to a research conducted by Alenzi (2010), 64 percent of the learners give more respect to the educators, who tend to use L1, while executing the lectures and students feel belonged in that class.

On the contrary, Abdullah (2010) argues that students L1 should not be used in ESL classrooms so as to increase the exposure of learning the target language. The more the L2 lessons are conducted, the quicker the learners will learn (Ellis, 2015). Yataganbaba \& Yildirim (2015) also recommends that learners L1 should not be used to teach L2. However, a few handfuls of teachers are of the opinion that code switching should be done at lower level and as the child progresses to higher, it should not be considered as a means for enhancing the teaching (Horasan, 2015). Students 
tend to highly appreciate monolingual classes as it enhances the learning and teaching the skills of the target language, without the interference of L1 (Tsukamoto, 2012). Some of the learners also believe that code switching is ineffective way to achieve feat in L2 (Ling et al, 2014).

\section{Types of Code Switching}

Researchers in the field of applied linguistics have come up with a typological framework surrounding the phenomenon of code switching. Claims are being made that there are two types of code switching: metaphorical and situational (Heeti and Abdely, 2016). However, Poplock (1980), having a disparated perspective states a well-known framework that ascertains three dissimilar types of code switching, which are inter-sentential, intra-sentential and extra-sentential (also known as tag-switching). This paper will look into the views of Poplock (1980).

\section{Inter-sentential Switching}

Inter-Sentential code switching involves switching at sentential limits, where one sentence or clause is in L1 and the next sentence or clause is in L2. According to Eldin (2014) and MacSwan (1999) inter-sentential switching entails fluency in both L1 and L2 of the speakers such that the speakers are able to apply the rules of the two languages. For example, if you are not going to eat your breakfast, tum kamjor mehasuus kare lagega. (Translation: If you are not going to eat your breakfast, you will start to feel weak).

\section{Intra-sentential Switching}

Intra-Sentential code switching takes place in the middle of a sentence, with no interruptions, hesitations or pauses indicating a shift. Here, the speaker is usually unaware of the shift. Different types of switch occur within the clause level including within the word level. This switching is considered to be the most complex one of all as it takes place at clausal, sentence and word level (Ariffin \& Galea, 2009). For example: You are sleepy veigaunakece because you spend a lot of gauna watching videos on YouTube. (Translation: You are sleepy most of the time because you spend a lot of time watching videos on YouTube).

\section{Extra- sentential/Tag Switching}

Extra-Sentential or Tag switching usually involves insertion of a short phrase or tag in one language into an utterance, that is, otherwise entirely in another language. This type of code switching is considered to be the most easy to use for the fact that its tagging typically contains minimal syntactical restrictions, thus not violating syntactic rules, when being inserted into monolingual sentences. Tags such as I mean, I wish, you know etc. are considered for this kind of switching. An example for this would be ee ladki thoh Rakiraki kehai! uutoh ekdam dehaati rakam baat kare hai! Areh gawarin! You know! (Translation: This girl is from Rakiraki! She is talking like a typical villager! Oh uncivilised! You know!)

\section{Reasons for Code Switching}

This part of the paper is going to look into the reasons why teachers switch codes. These reasons have been extensively observed from numerous linguistic perceptions. The reasons are based on the conceptual framework designed by Appel and Muysken (2006) functional model of code switching. The bilinguals and monolinguals are expected to switch from one code to another either to distinguish oneself, to show solidarity, to engage in social interactions, to talk about certain topics, to express affections and feelings and to persuade or impress the audience.

\section{To show solidarity}

Janet Holmes in her book Introduction to Sociolinguistics stipulates 'a speaker may...switch to another language as a signal to group membership and shared ethnicity within an addressee...' (Holmes, 2017). Code switching can be used to show solidarity between people of different or similar ethnic group.

\section{To distinguish oneself/engage in social interactions}

It is highly observable that speakers tend to use different languages to relate themselves to certain societal status or distinguish each other from social classes. One interesting reason that has been noticed is that code switching is done by users to sound classy or elitist. In a book written by Professor Auer Code Switching in Conversation: Language Interaction and Identity, he has precisely mentioned that, when it comes to switching codes a hidden prestige is made explicitly by the attitudes of the users (Auer, 2013). Another interesting research by Al-Khatib (2003), states that speakers may be doing code switching to show their power over the less powerful.

Therefore, now a connection could be made that switching codes in between the spoken conversation is a means to reflect one's social class. On the same note, a speaker who confidently switches codes implies that he/she is well educated and by all means is able to competently apply the language skills of L1 and L2 in spoken conversation. Thus, code switching could be looked as a way to distinguish oneself in any given society. In brief, as asserted by Suleiman (1999), the phenomenon surrounding code switching is highly prevalent in any given bilingual and multilingual communities, as it talks about self-prestige, sign of education and a competence in more than one language.

\section{Topics}

On the other hand, topic seems to be another imperative reason that makes a bilingual speaker to switch codes. People may tend to code switch within a speech event, mainly to talk on a particular given topic (Holmes, 2000). Thus, speakers may use more than one language within the same utterance suiting the topic of the discussion. In most of the instances, a bilingual speaker chooses one language within one utterance suiting the topic of discussion. A highly observable note which is being made in the Fijian ESL classrooms is when students are being counseled for disciplinary cases and the counselor tends to use L2 of the student being counseled. In this way, the emotionally disturbed child 
feels belonged and secured, thus the 'topic' of discussion becomes much simpler.

Also, words that are taboo and 'topics' that cannot be discussed openly and freely would require L2 depending on the sensitiveness of the subject (Lueng, 2006). In a study conducted by Abalhassan \& Shalawi (2000), twelve students were interviewed and asked a question based on a 'sensitive topic', why did you choose your L1 to give your response? The startling answer which caught the attention of the researchers was that...because I can't say taboo words using my mother tongue.

\section{Affection}

Code switching can also be seen a means to express attitudes and feelings by a speaker during different scenarios. Speakers pour out their feelings and emotions through expressions such as anger, frustration, happiness, sadness, excitement, crying and many other feelings. Why do people come up with these kinds of emotions and feelings? Janet Holmes in her book Introduction to Linguistics precisely stipulates that...A switch in a language...is often considered to be a sign of disapproval. For example, when a child creates a tantrum in a supermarket over some exorbitant toys and parents do not have that much money to spend, then out of anger, they start to scold him/her in their L2 to avoid the child from creating a scene.

Another example as highlighted by Al-Khatib (2003) was in a small town of Oberwart, where two Hungarian speaking children were playing and accidently knocks down a stack pile firewood. Their grandfather walks in and tells them off in Hungarian... 'Szo! Idedzuni! jesztjeramunyi mind e kettutoko, no hat akkor! [Well come here! Put all this away! Both of you! Well now!]. Upon hearing this, when the children did not come, the grandfather quickly switched into German language and it did had a quick effect on the children (Holmes, 2000).

\section{Audience persuasion}

Code switching is applied in order to welcome someone new to a communicative event. According to Malik (1994), this communicative event could take place over different linguistic backgrounds or from the same as asserted by Holmes (2001, p.35). Code switching is also used during rhetoric and speech. The sole purpose of it is to attract and persuade the audience. As highlighted by Nerghes (2011), doing a code switch will draw the attention of the participants and will equally enhance their motivation to cautiously scrutinize the messages being presented. When a speaker is going to use code switching in rhetoric and persuasive language, they will be in a far better position to be successful in serving the purpose of switching codes, which eventually leads to achieve their goal.

\section{Code Switching by Teachers in Bilingual and Multilingual classroom settings}

In any given ESL classroom settings, the target language becomes the goal and means of L2 acquisition. However, the existence of L1 in the classroom ambience for both the teachers and learners could substantially influence the spoken behaviour of both the users, which can lead to situations of code switching. As stated by Macaro (2005), code switching is available specifically to bilinguals and is considered to be a natural phenomenon in any given classroom interaction. Although the teachers are expected to execute the ESL classes in the target language, most of them perpetually have no option but to resort to L1 to tackle number of classrooms issues surrounding the learners (Makulloluwa, 2013).

Illustrating this, Turnbull \& Arnett (2002), had identified three macro-functional categories of code switching in any L2 classrooms. According to Turnbull and Arnett (2002), teachers tend to use learners L1 for various pedagogical reasons, secondly, to build an effective and sound relationship with the students and thirdly to have order and discipline in the classroom. In the same capacity, supporting the functional categories of the above, Polio \& Duff (1994) explored the teachers' classroom language in L1 milieu and revealed that learners' L1 was mainly considered for classroom management, show solidarity, aid comprehension and offer translation of words and grammar instruction. On the other hand, Canagaraja (1995) studied the functions of code switching in Sri Lankan ESL classroom and identified a division of labour between the two languages, English (TL) and Tamil (L1). According to his findings, L1 was used to maintain a soft personal interaction with the learners, while L2 was seen as a pedagogical need. In short, the functions of code switching identified by Canagaraja refute the claims made by Turnbull and Arnett. Canagaraja has noted many functions of code switching, while Turnbull and Arnett sees code switching only to be used for pedagogical reasoning's.

\section{FINDINGS AND DISCUSSIONS}

The findings of the questionnaire and the semi-interview are stipulated as follows:

Elucidating meaning and vocabulary - The pie chart figure 1.0 below depicts that $68 \%$ of the respondents reported that they agreed or strongly agreed to the statement that using L1 assists them in elucidating meanings and new vocabulary, especially to mediocre students in ESL classrooms. On the other hand, $32 \%$ of the respondents had either strongly disagreed or were neutral with the statement. This suggests that ESL teachers consider code switching as a useful strategy in teaching meaning and vocabulary in English language. This assists the students to fathom the lesson in a much better way, as they were able to respond to the teachings, which they could not fully understand by the use of L2. So much so, the teachers also commented that they felt content after getting the optimistic feedback from the students.

This was indeed considered to be a better way to make students understand difficult concepts and at the same time expanding their horizons to know what actually is going on in the $E S L$ classroom. However, this was only applicable to one on one student guidance and not for the whole class lesson execution. 


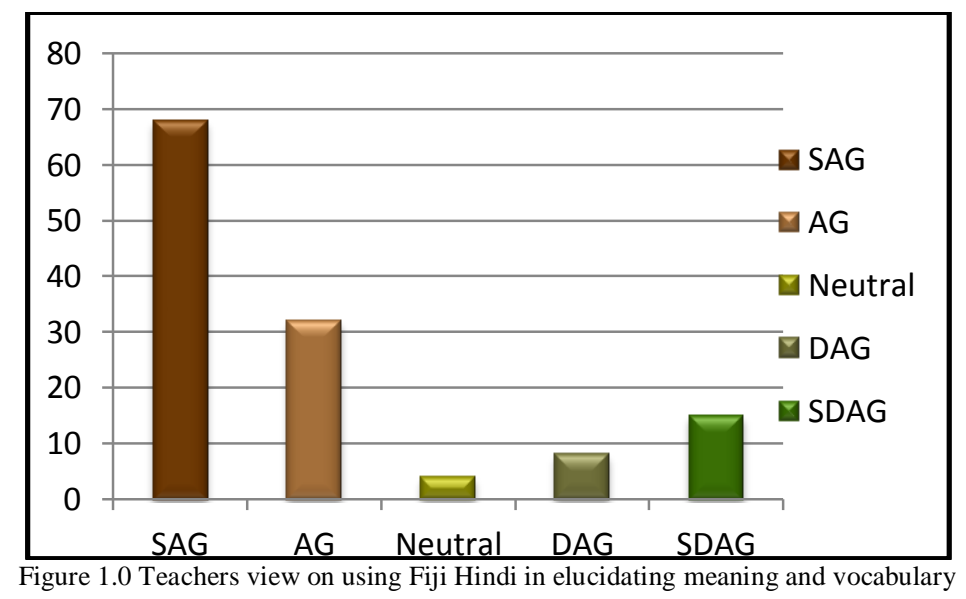

Assisting interpretation - Figure 2.0 stipulated below explores whether L1 assists learners in fathoming complex contents of English classrooms. 64\% of the respondents strongly agreed and agreed that learner's L1 was highly helpful in comprehending complex topics in ESL classroom. On the other hand, 36\% were rather neutral, disagreed or strongly disagreed.

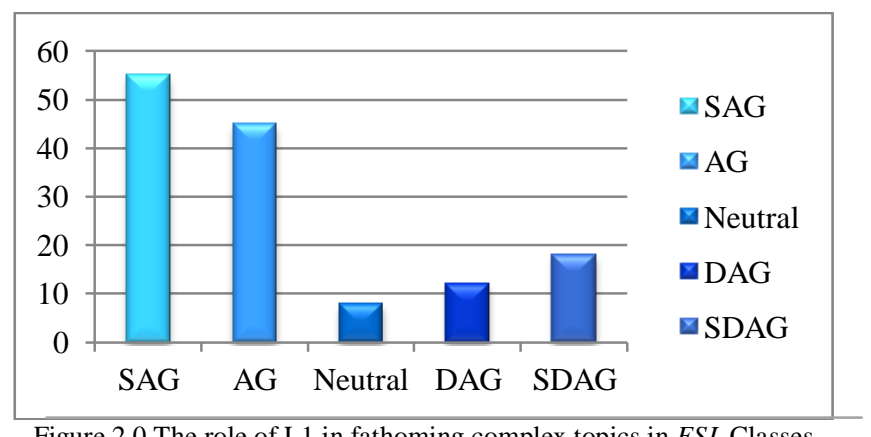

Figure 2.0 The role of L1 in fathoming complex topics in ESL Classes

Looking at the following sentential examples, there has been certain focal point that needs to be elucidated by using either one or two words.

T: haaneela, last point (Yes, this last point). Alright! Aur ekko? (Alright! Any other?). Haan, isse pahelelaa (Yes, before this).

Further, one or two words of Fiji Hindi were used for the students as an assistance to focus on the interpretation of a comprehension passage. Words such as haa (yes), yane (means), konla? (which one?) hai ki nai? (is it not so?) acha! dekhi jaaye (okay! let's see).

During the interview, some of the teachers claimed that student's L1 was used to provide guidance for the interpretation of sentences, phrases and paragraphs of the particular subject matter.

The use of L1 in ESL classrooms gives most of the learners any array of opportunity to fathom well.

These findings precisely depicts that L1 has served a repertoire of pedagogical functions, which also includes guiding interpretation (Adendorff et al, 1993). This particular situation was also proven by the findings of the studies being conducted in Greece by Prodromou (2000).

The findings revealed that both teachers and students alike in Greece tend to use L1 in their English classes for a repertoire of reasons at beginner and intermediate level.

This has been overwhelmingly accepted as a strategy to assist learners in fathoming various contexts in ESL classrooms. As such, this purely justifies why Atkinson (1987) and Cook (2001) called for using code switching in ESL classrooms with the belief that it is a natural phenomenon, which tends to assist students in terms of comprehending topics, concepts and contexts. Furthermore, as acclaimed by Muir (2001), L1 is seen as a conscious strategy to look into the meanings, hence promoting active classrooms interactions.

Transmission of the lesson content - Figure 3.0 below shows that most of the respondents $81 \%$ strongly agreed that translating phrases, sentences and words to comprehend the messages in ESL classrooms tends to give the assurance that the students have fathomed the lesson. Yet, $19 \%$ of them were neutral or undecided, disagreed or strongly disagreed with the statement. 


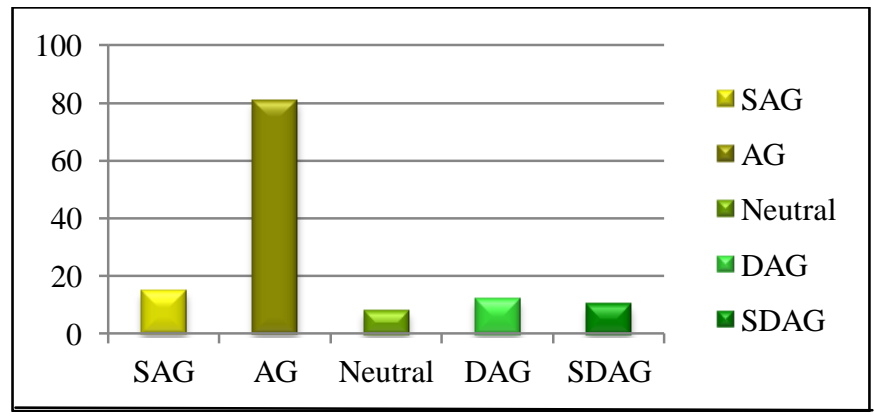

Figure 3.0 The role of translation in fathoming English texts

The excerpt stated in Fiji Hindi is used to assist learners fathom the rest of the sentences and the paragraphs. It could be considered as a scaffolding strategy to comprehend the contextualised meaning in the sentence. The below mentioned excerpt has the conversation of a teacher, which takes place between one on one encounter with a student and starts as such:

T: konchi seekha tum ee short story se? (What have you learnt from this short story?)

S: hum seekha ki hum logke kabhi wrong decisions nai banaaye ke chahiye, naithoh fir pachtaaye ke padi (I have learnt that we should not make wrong decisions, or else we are going to regret).

T: Acha, theekhai! aur ekko? (Okay, alright! Any other?)

Interpreting the above excerpt, in the first line Fiji Hindi has been used to elucidate the situational context, whereby the teachers asked the student what the message from the short story being studied was. In the second line, the student responds to the teacher's question, while in the third line the teacher praises the student and asks for any other message from the short story. The Fiji Hindi meaning and the English vocabulary were used in the sentences: started with Fiji Hindi (for meaning explanation), later English was used for the contextual setting.

Similar studies by Canagarajah (1995) concurred that ESL teachers, while considered L1 inappropriate for English classrooms, unconsciously used it in a beneficial way, such as translating language content for mediocre and below mediocre students. As asserted by Adendorff (1993), code switching serves an imperative academic and social function in the repertoire of environment, which includes classroom management, class activity explanation, interpretations and fathoming social relationships.

Illustrating rules of the grammar - Figure 4.0 below looks into the analysis of teacher's use of student's L1 to illustrate grammatical rules. 55\% of the respondents agreed and strongly agreed that they used learner's L1 to elucidate difficult grammatical rules and points. On the other hand, $45 \%$ of the respondents reported that they were either neutral, disagreed or strongly disagreed.

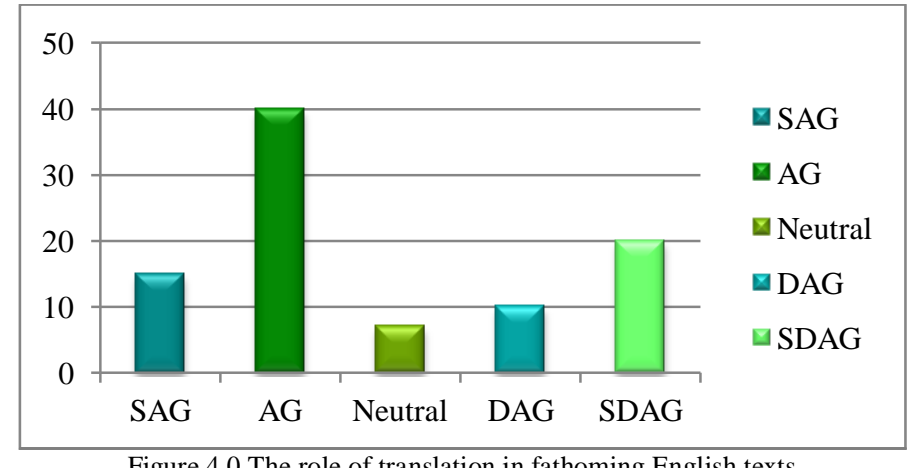

Figure 4.0 The role of translation in fathoming English texts

In some of the interactions, certain Fiji Hindi vocabulary shows that there is a discussion, while making students fathom complex grammatical rules. This is in a formulaic form: waha pe verb hai (there is a verb), haa hum logke jane ke chahiye... (yes, we shall know...), yaha pe hum log sakta dekhe ki uu aawe hai (as we can see it comes with) 'to', hai ki nai? (is it not so?), theek (okay), yaha pe bhi certain expressions hai (there are certain expression here too), yaha pe bhi uu bolis hai(he also said here).

In the following excerpt, it is shown how Fiji Hindi words have been used to explain infinitive verb:

$\mathrm{S}$ : yaha pe infinitive verb hai(here is an infinitive verb)

T: hum logke jane ke chahiye (we shall know the) 'infinitive form'. In English, there are two types of infinitive forms samjha, acha se! (understood, well!). Infinitive with 'to'...

T: jaise hum log yaha per dekha, 'to' with ke sathe aawe hai (as we noticed here, it comes with) 'to', as in 'enemy decided to...', iske matlab hai 'decided', (it means that after the verb 'decided', infinitive verb 'to' follows).

The results from the above figure and the conversation are precisely supported with some of the statements of the teachers who mentioned in the interview to use L1 in elucidating the rules of grammar in English. 
I mainly tend to use L1 with one on one coaching illustrating the grammar rules, especially those which mediocre students are not able to understand, when it is first introduced to them.

I preferred to switch in L1 during the grammar teaching classes, again in one on one coaching.

The unconscious use of L1 in teaching grammatical rules has been confirmed by some studies relating to bilingualism. As asserted by Prodromou (2000), beginner students confirmed that it was really helpful to elucidate the differences between L2 and L1 grammar. However, highly competence students did not see much effectiveness in explaining the grammatical differences.

Organising the classroom - Figure 5.0 below shows the effectiveness of code switching to maintain classroom discipline. $64 \%$ of the respondents expressed optimistic attitudes towards using L1 in classroom management, while $36 \%$ of the respondents were neutral, disagreed and strongly disagreed. In the process of controlling the classroom management, teachers often go through a lot of challenges. Most of the time many students tend to ignore teacher's instructions and exhibit unwanted behaviour in the classroom. Considering this behaviour, most of the teachers tend to lose out their patience and switch to L1 to make students disciplined. According to the respondents, it was pretty easy to maintain the unwanted behaviour with the use of L1 because the students were disciplined using certain words, which L2 didn't have. As such, most of them listened to the teacher and displayed the accepted behaviour of the classroom.

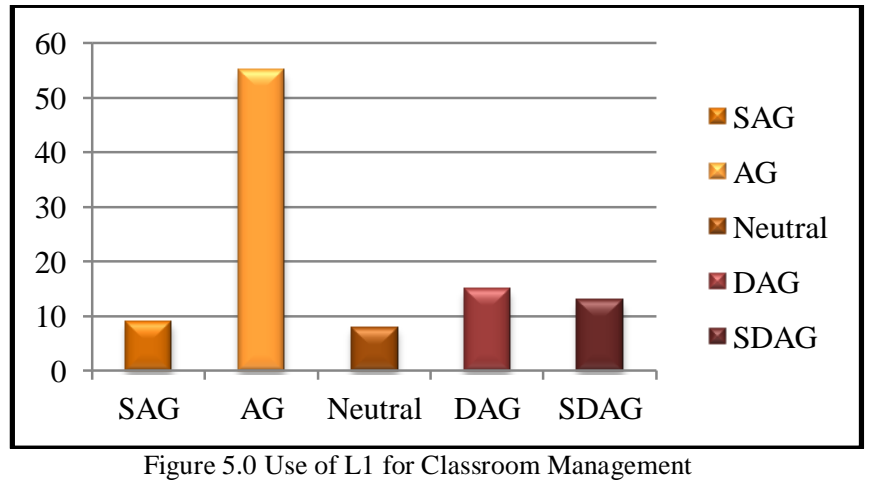

In the following excerpt the teacher uses L1 with highly blatant students, who exhibited carefree attitude in the classroom.

T: Rahul! tum kahe waise baat karta hai? Chuppe muh bandh karke group mei kaam nai sakta kare? (Rahul! Why are you talking like that? Can't you shut your mouth and participate with the group?)

Many studies have supported the claims that using L1 in L2 classroom management will bring in the utmost discipline in the classroom. As argued by Macaro (1997), some educator's switched to learner's L1 after failing to keep up a group activity, when using L2 only. It has been noticed that this was the time, when students would fail to participate in the group activity and start to play around. Macaro also emphasises that excluding learners L1 would lead to deprivation of an imperative vehicle for language learning. Al Dosari and Storch (2010), also mentions that students L1 has been seen as a useful tool in organising L2 classroom discipline. More precisely, Jingxia (2010), found that the use of L1 in L2 classroom was used to manage classes for the sole reason to oversee students would not violate classroom discipline. It was also reiterated that L2 teachers would mainly switch to L1 to criticise and maintain the discipline in the classroom.

\section{CONCLUSIONS}

Throughout this paper, the functions and the need for code switching in ESL classroom has received optimistic, as well as pessimistic criticisms. According to the respondents, most of have them believed that the use of L1 is unavoidable in L2 classrooms. In Fijian ESL classrooms, where teachers and the students share the same L1, there is a strong tendency that L1 will be used in various activities for effective learning and teaching. For obvious reasons, L1 is used more naturally with others, who share it for easy and effective communication reasons. So much so, the usage of L2 all the time could be a contributing factor towards embarrassment for shy students, particularly those who may not be competent in the target language. Having this mentioned, L1 is crucially imperative in the process of L2's effective teaching execution.

The present study findings have also revealed that teachers see L1 uses as an acceptable belief towards the repertoire of pedagogical uses of Fiji Hindi to execute interactions of ESL teaching, that is, elucidating meaning and newly introduced vocabulary, assisting interpretation, transmission of the lesson content, illustrating rules of the grammar and managing the ESL classrooms.

Code switching, then could be seen as a linguistic resource in ESL classrooms for the variety of functions that it posits in teaching English as a second language. Consequently, L1 use in the ESL classroom should not be seen as something that may discourage the learners from learning L2, in fact, it should be seen as a linguistic tool to assist mediocre or below mediocre students to gain competency in the target language. 
Therefore, the notion of total prohibition of L1 in Fijian ESL classroom was not favoured by all the respondents surveyed in this study. The implication of this would be that the exclusive use of English only in the class maybe detrimental to effective L2 teaching and learning. Consequently, L1 use in the ESL classrooms should not be ignored either, as it tends to allow the learners to help better fathom L2. Cook (2001) ascertains that L1 usage in the ESL classroom contributes significantly towards the current teaching pedagogies, which may allow new developments in ESL methodologies.

So much so, the findings also imply that there is a dire need for new policies to be included in the existing language policies so that the concept of code switching can be seen as an imperative communicative tool in the Fijian ESL classrooms. Having this given the favour, the new implementation can provide remedial measures to most extent in removing potential hiccups that may be experienced in the process of teaching English as a second language, especially for those learners, who are surviving on the brink to achieve the highest level of competency.

As teachers of English as a second language, one cannot deny the fact that he or she does not switch, while executing lessons in ESL classroom. Therefore, the English curriculum developers should condone "English only using policy" and pave way for L1 usage for the sole purpose to assist those learners, who are mediocre or below mediocre. In this way, the phenomenon of code switching will be redefined and made practical in the Fijian ESL classrooms contributing significantly towards the deplorable state of English in Fiji.

\section{REFERENCES}

[1] Abalhassan, K. M., \&Alshalawi, H. G. (2000).Code-switching behavior of Arab speakers of English as a second language in the United States. Intercultural communication studies, 10(1), 179-188.

[2] Abdullah, A. (2010). Students' language attitude towards code-switching as a medium of instruction in the college of health sciences: An exploratory study. Annual Review of Education, Communication and Language Sciences, 7(1) 1-22.

[3] Abdolaziz, R., \& Shahla, S. (2015). Teachers and students' perceptions of code switching in aviation language learning courses. International Journal of Research Studies in Language Learning, 5(3), 3-18.

[4] Adendorff, R. (1993). Code-switching amongst Zulu - speaking teachers and their pupils: Its functions and implications for teacher education. Language and Education, 7(3), 141-162.

[5] Ahmad, B. H., \& Jusoff, K. (2009). Teachers' code-switching in classroom instructions for low English proficient learners. English Language Teaching, 2(2), 49-55.

[6] Appel, R., \& Muysken, P. (2006). Language contact and Bilingualism.Amsterdam: University Press.

[7] Ariffin, K., \&Rafik-Galea, S. (2009). Code-switching as a communication device in conversation. Language \& Society Newsletter, 5.

[8] Atkinson, D. (1987). The mother tongue in the classroom: A neglected resource?. ELT journal, 41(4), 241-247.

[9] Auer, P. (Ed.). (2013). Code-switching in conversation: Language, interaction and identity. Canada: Routledge.

[10] Azlan, N. M. N. I., \& Narasuman, S. (2013). The role of code-switching as a communicative tool in an ESL teacher education classroom. Procedia-Social and Behavioral Sciences, 90, 458-467.

[11] Bentahila, A. (1983). Language attitudes among Arabic-French bilinguals in Morocco. Clevedon: Multilingual Matters.

[12] Canagarajah, A. S. (1995). Functions of codeswitching in ESL classrooms: Socialising bilingualism in Jaffna. Journal of multilingual \& multicultural development, 16(3), 173-195.

[13] Cohen, L., Manion, L., \& Morrison, K. (2002).Research methods in education. London: Routledge.

[14] Cook, V. (2001). Using the first language in the classroom. Canadian modern language review, 57(3), 402-423.

[15] Creswell, J. W. (1998). Qualitative inquiry and research design: Choosing among five traditions. USA: Sage Publications

[16] Eldin, A. A. T. S. (2014). Socio linguistic study of code switching of the Arabic language speakers on social networking. International journal of English linguistics, 4(6), 78-90.

[17] Ellis, R. (2015). Understanding Second Language Acquisition 2nd Edition-Oxford Applied Linguistics. Oxford: Oxford university press.

[18] Fareed, M., Humayun, S., \&Akhtar, H. (2016). English Language Teachers' Code-switching in Class: ESL Learners' Perceptions. Journal of Education \& Social Sciences, 4(1), 1-11.

[19] Hosoda, Y. (2000). Teacher code switching in the EFL classroom. JALT journal, 22(1), 69-93.

[20] Heeti, N. A \& Abdely, A.A. (2016). Types and Functions of Code Switching in the English Language used by Iraqi Doctors in Formal Settings. International Journal of Advanced Research and Review, 1(8), 10-18.

[21] Higareda, S., López, G., \& Mugford, G. (2009). Duermes mucho Tony?: Interpersonal and Transactional Uses of L1 in the Foreign-Language Classroom. Profile Issues in Teachers Professional Development, 11(2), 43-54.

[22] Holmes, J., \& Wilson, N. (2017).An introduction to sociolinguistics. New York: Routledge.

[23] Holmes, J. (2000). An introduction to sociolinguistics (2nd ed.). Wellington: Longman.

[24] Holmes, J. (2001). An introduction to sociolinguistics (2nd ed.). London: Pearson Education Limited.

[25] Horasan, S. (2014).Code-switching in EFL classrooms and the perceptions of the students and teachers. Journal of Language and Linguistic Studies, 10(1), 31-45.

[26] Hymes, D. (1972). On communicative competence. Sociolinguistics, 269-293.

[27] Jingxia, L. (2010). Teachers' code-switching to the L1 in EFL classroom. The Open Applied Linguistics Journal, 3(10), $10-23$.

[28] Krashen, S. D. (1982). Principles and practice in second language acquisition. University of Southern California: USA

[29] Ling, L. Y., Jin, N. Y., Tong, C. S., Tarmizi, M. A., \&Sahiddan, N. (2014). Influence of an English Lecturer's code-switching practice on Students' Confidence in the subject. International Journal of Asian Social Science, 4(2), 226-233.

[30] Leung, C. (2006). Code switching in print advertisements in Hong Kong and Sweden. Sweden: Lund University Press.

[31] Lynch, J. D. (1996). Pacific languages in education.editorips@ usp. ac. fj. Vanuatu: Bluebird Printery Limited. 
[32] Macaro, E. (2005). Code switching in the L2 classroom: A communication and learning strategy. In Non-native language teachers (pp. 63-84).Springer, Boston, MA.

[33] Macaro, E. (1997). Target language, collaborative learning and autonomy (Vol. 5). Multilingual matters. Britain: WBC Book Manufacturers Limited.

[34] MacSwan, J. (1999). A minimalist approach to intra-sentential code-mixing: Spanish-Nahuatl bilingualism in central Mexico. New York: Garland.

[35] Malik, L. (1994). Socio-linguistics: A study of code-switching. India: Anmol Publications PVT.LTD.

[36] Makulloluwa, E. (2013). Code switching by teachers in the second language classroom. International Journal of Arts \& Sciences, 6(3), 581-598.

[37] McKinnon, D. E. (2016). Examining Women's Participationin Leadership Rolesat the Grassrootsin Rural Fiji: The Case of Votua, Ba. Suva: USP Press.

[38] Moghadam, S. H., Samad, A. A., \& Shahraki, E. R. (2012). Code Switching as a Medium of Instruction in an EFL Classroom. Theory \& Practice in Language Studies, 2(11). 2219-2225.

[39] Muir, K. (2001). Code-switching in EFL teacher discourse. Unpublished Master of Applied Linguistics thesis: Macquarie University, Sydney, Australia.

[40] Nerghes, A. (2011). The impact of code-switching on persuasion: An elaboration likelihood perspective. Wageningen University.

[41] Nordin, N. M., Ali, F. D. R., Zubir, S. I. S. S., \& Sadjirin, R. (2013). ESL Learners Reactions Towards Code Switching in Classroom Settings. Procedia-Social and Behavioral Sciences, 90, 478-487.

[42] Polio, C. G., \& Duff, P. A. (1994). Teachers' language use in university foreign language classrooms: A qualitative analysis of English and target language alternation. The Modern Language Journal, 78(3), 313-326.

[43] Poplack, S. (1980). Sometimes I'll start a sentence in spanish y termino en espanol: toward a typology of code-switching1. Linguistics, 18(7-8), 581-618.

[44] Prodromou, L. (2000). From mother tongue to other tongue. TESOL Greece Newsletter, 67, 7-8.

[45] Sert, O. (2005). The Functions of Code-Switching in ELT Classrooms. Online Submission, 11(8). 1-6.

[46] Storch, N., \& Aldosari, A. (2010). Learners' use of first language (Arabic) in pair work in an EFL class. Language Teaching Research, 14(4), 355-375.

[47] Swain, M., \& Lapkin, S. (2000). Task-based second language learning: The uses of the first language. Language teaching research, 4(3), 251-274.

[48] Tsukamoto, M. (2012). Students' perception of teachers' language use in an EFL classroom. 10(2). 143-154.

[49] Turnbull, M., \& Arnett, K. (2002). 11. Teachers' uses of the Target and First Languages in Second and Foreign Language Classrooms. Annual review of applied linguistics, 22, 204-218.

[50] Valdes-Fallis, G. (1978). Code-switching among bilingual Mexican-American women: Towards an understanding of sex-related language alternation. International Journal of the Sociology of Language, 1978(17), 65-72.

[51] Willans, F. (2011). Classroom code-switching in a Vanuatu secondary school: Conflict between policy and practice. International Journal of Bilingual Education and Bilingualism, 14(1), 23-38.

[52] Yatağanbaba, E., \& Yıldırım, R. (2015). EFL teachers' code switching in Turkish secondary EFL young language learner classrooms. International Journal of Linguistics, 7(1), 82-101.

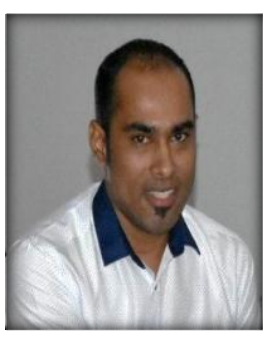

Ravnil Narayan is a Lecturer in Language and Communications in the College of Humanities and Education: School of Communication, Languages and Literature at the Fiji National University's, Ba Campus. He holds a MATESL, PGDTESL, BEd, DSE, DPVL, DHL qualifications. Currently, he has invested in his second Postgraduate studies in Applied Linguistics from the University of the South Pacific. As a former high school English language teacher and an ad hoc translator with AQEP AusAid (Fiji), Ravnil's area of interest lies in the field of sociolinguistics, computational linguistics, first language acquisition and e-language learning education. He is also a columnist with The Fiji Times and has published articles in ranked journals before. As for his future aspirations, Narayan tends to invest in his PhD in Applied Linguistics. Ravnil hails from the beautiful islands of Fiji in the South Pacific and can be contacted on ravnilnarayan@gmail.com. 